\title{
Na arquitetura, \\ a apoteose do \\ popular
}

Telmo Pamplona *

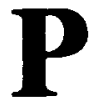
ara aquele motorista de táxi amarelo, ex-adepto da campanha brizolista, o dinheiro público aplicado no Sambódromo deveria ser gasto no aumento negado às "professorinhas". No rádio de domingo, o locutor com a voz americanizada anuncia pela Transamérica FM a balada "Banana Republic", dedicada a "todos os gringos que moram no Rio". Você pega o metrô em Botafogo, vai direto pro Estácio, e chega ao Sambódromo, ou Passarela do Samba, ou Avenida dos Desfiles e o encontra fechado, vazio, guardado pela PM.

Impossivel não mergulhar neste mar de impressð̃es contraditórias, neste fluxo de fatos e idéias que se movem em sentido contrário, para "cair na real" do Rio-Brasil. Triste realidade: os salários são os mínimos. A habitação é precária, sem espaço nem equipamento urbano. O transporte corre a hora livre. O lazer é futebol, é Sílvio Santos. Depois, os filhos. Fila de INAMPS. E a morte. Os bairros proletários se transformaram num imenso depósito urbano de mão-de-obra barata.

* Telmo Pamplona é arquiteto.
Diante desse quadro, não é de admirar que o carnaval, grande mobilizador das massas cariocas, assuma a força que tem. Segundo seus realizadores, o sambódromo corresponde às expectativas dessa gente sofrida. Será verdade?

Inserido na antiga " zona do mangue" carioca, rodeado pelas favelas, existiria uma arquitetura adequada para o Sambódromo? O projeto é simples e eficaz: foi estruturado sob a forma de "módulos" de arquibancadas (como nos estádios de futebol), extensos planos inclinados que no seu interior guardam as salas de aulas. Em frente às arquibancadas, num bloco único e comprido, quase encostado na fábrica Bhama, foram dispostos os três níveis de camarotes, que acabam também dando uma referência teatral ao espaço projetado.

Este conjunto de arquibancadas e camarotes abriga, perfeitamente, o desenvolvimento do desfile tradicional das escolas de samba, antes realizado na via pública. Ao complementar o projeto, entretanto, com a abertura de uma grande "praça" da apoteose, simplesmente o projeto reabre a discussão da estrutura do desfile tradicional, que antes se desenvolvia apenas linearmente na avenida. Entra-se no espaço da 
dança, indutor de uma nova "coreografia"' e, neste processo, se rediscute também cultura popular.

Os "módulos" de arquibancadas se assentam sobre uma estrutura de arcos de concreto, o que garante a continuidade do espaço ao nível da rua. Esta mistura de "rua de desfile", espaços cobertos contínuos sem vedação e o grande pátio descoberto (a praça da apoteose) sugerem a apropriação imediata da área por parte da população circunvizinha (atenção, assessores do governador Brizola: parem de "guardar" o Sambódromo para shows e o entreguem à sua própria sorte...), como espaço de lazer e mesmo de trabalho (uma vez devidamente equipado), à moda do que já hoje se faz nas quadras das escolas de samba, por vezes o único espaço comunitário de bairros suburbanos e favelas.

A genialidade do projeto consiste exatamente nesta proposta de "co- lagem" urbanística apropriada, onde uma arquitetura de concreto aparente, com forma diferente do que existe ao seu redor, pode com ele se integrar, compatibilizando o uso para desfile de escola de samba com o uso para reuniões, espetáculos, atividades escolares, vida comunitária.

O sambódromo tem formas extremamente sóbrias. Pode-se até confundir a simplicidade adotada como uma "falta de inspiração" do arquiteto. Julgo, entretanto que, nesta obra, Niemeyer conseguiu o que durante toda sua carreira perseguiu: realizar uma obra radicalmente popular.

No fundo da praça da apoteose fica o Museu do Samba, com sua "alegoria". O que significa? Para alguns, o M do MacDonald's. Para outros, uma bunda de mulata. Para mim lembra o olhar da incerteza que ainda paira sobre nós...

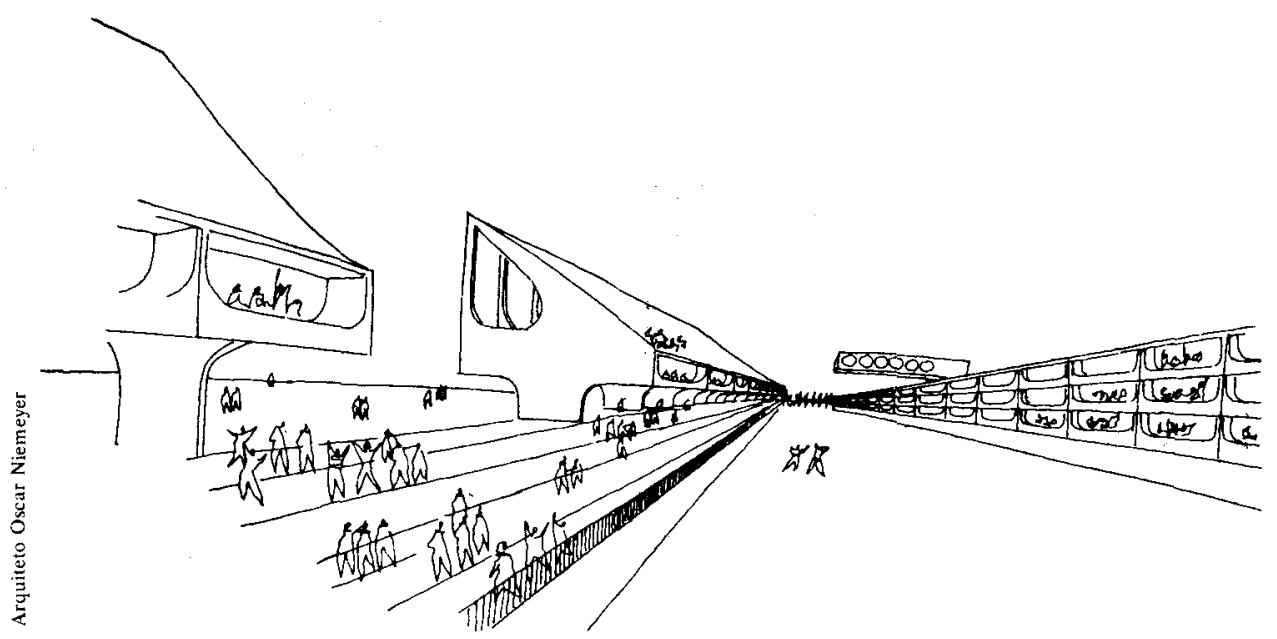

